\title{
Open Shelves/Closed Shelves in Research Libraries
}

\begin{abstract}
This article traces the traditional method of making books accessible through their topical arrangement on library shelves, outlines the reasons for the abandonment of this method in European research libraries, explores its modified reappearance in postwar academic libraries, and cites modern arguments against the practice of making an entire research collection available on open shelves.
\end{abstract}

A

Merican libraries of all kinds endeavor to make books easily accessible, and as a result most libraries open their shelves to their readers. This practice does not prevail, however, in all libraries throughout the world. Large academic research libraries abroad usually have closed stacks, and scholars gain access to these collections through catalogs, bibliographies, and indexes.

The maintenance of open stacks with materials accessible through a classified arrangement is very costly. In view of modern research needs and budget pressures experienced by libraries, the high costs involved in this practice become more and more questionable and require justification. To explore this issue, this paper will trace the tradition of open access; outline reasons for its abandonment in European research libraries; demonstrate its reappearance in modified form since World War II, particularly in German libraries; and cite modern arguments which challenge the validity of classifying the holdings of a research library on the shelves for the benefit of those who wish to browse.

If one defines a library as a collection

Mathilde V. Rovelstad is professor, Department of Library Science, Catholic University of America, Washington, D.C. organized for use, access to it is essential. The question then becomes whether this access is more successfully accomplished through the use of traditional bibliographical sources or through the bibliothecal approach which allows browsing in the shelves. Most foreign academic and research libraries arrange their collections in a chronological sequence according to the order of acquisition by the library. Browsing in such a situation is meaningless since books of different subject fields are placed next to each other; and without special notational provisions individual volumes of a work, or monographs in a series, are not kept together. This practice is directly opposed to that used in American libraries where books are classified and available on open shelves.

\section{The Tradition of Open Shelves}

Historically, open access to shelves, where books are placed together by subject, is the oldest and simplest way of providing for the use of a collection. It is a method successfully demonstrated in most private libraries, and is a very economical retrieval device for any small collection. Even though little is known about early practices in library organization, it is obvious that the ma- 
terial assembled in these libraries must have been arranged in some orderly fashion if it were to be retrieved easily. In fact, catalogs that have survived from antiquity indicate that some rough subject order already had been maintained for the tablets and rolls in earthen jars, wooden chests, wall niches, and later in the armaria of Roman times. $^{1}$

The monastery libraries which were dominant during the Middle Ages had very small collections compared with those of antiquity. They served communities of learned monks and lay persons with scholarly interests and religious backgrounds. For ease of use, the vernacular books, the "lay library," were usually separated from those used for study. Since they generally had to be used on location, a rough subject order was the typical form of organization. ${ }^{2}$ For a long time the arrangement itself had to serve as a finding device since there were no catalogs. This was possible because the collections were very small; even medium-size libraries did not have more than a few hundred codices. In larger collections there were headings to guide the user to the location of the literature. Pictures of authors on cupboards or walls would suggest the presence of related books, such as in the library of Isidore of Seville (560-636), or the furniture units themselves were designated, such as an armario imperiali in the library of Charlemagne (742-814). The monasteries of St. Gall and the Reichenau provided captions for sub-units. ${ }^{3}$

A unique medieval custom required a periodic inspection of library volumes and was still mentioned in Richard de Bury's Philobiblon. ${ }^{4}$ This practice was probably the reason why lists of the items contained in a furniture unit were compiled. The absence as well as the presence of a work could thus be checked. With growing collections these lists also facilitated the retrieval of the works in the library. Actually, they were early catalogs with a double function: as shelflists they provided inventory control and indicated location; and because related items were kept together, they also served as subject catalogs. It is evident that ease of access to the assembled books was of concern since a typical list displayed the titles in homogeneous groupings. For example, it would begin with the Bible, then list the Church Fathers, theologians, and antique authors, and end with the artes liberales. $^{5}$

After the twelfth century the period of the great monastery libraries came to an end, and universities emerged as the carriers of scholarly teaching and learning. Since their book collections served a more varied group than those of the monasteries, they included the profane disciplines taught at the colleges. The library at the college endowed by Robert de Sorbonne (1250) in Paris set the pattern for others. As in the monastery collections, books were arranged to suit the needs of their users. They were grouped according to the four faculties of the college: theology, medicine, law, and philosophy. Within each group there was a rough arrangement according to the first letter of the author's name. But even this order was not strictly maintained since works were comparatively easy to find in the small collections. In 1289 the Sorbonne library was divided into a noncirculating reference library (libraria magna) with 330 volumes, of which the heavily used books were chained to twenty-six desks, and a small circulating library (libraria parva) with 1,290 books consisting of duplicates and less valuable items. ${ }^{6}$

The Renaissance and Baroque age could boast beautiful library roomsarchitectural gems-in royal and princely residences. Books were stored in alcoves on series of tiers surrounding 
great halls. The owners generally allowed a congenial public the use of their collections in these halls, but with the spreading of education there were already demands from a larger public for access to the knowledge stored in libraries. Gabriel Naudé (1600-1653), in his famous treatise on library practice, suggested that libraries should be open for public use and available to "the humblest of those who may reap any benefit thereby." 7 The circle of people admitted became larger when some libraries opened their doors to the "public," which meant at that time learned individuals who were not members of the immediate academic community. The Ambrosiana in Milan (1603) was the first large library adopting this liberal policy, and it was soon imitated by others, such as the Bodleian at Oxford (1612) and the Mazarine in Paris (1643). Cardinal Richelieu (1585-1642) wanted the Sorbonne also to be a "public" library where scholars would be admitted at certain hours daily, as well as "messieurs les curieux et les étrangers," that is, outsiders not known to the academic community. ${ }^{8}$ This public still represented a very small and select group of individuals and certainly did not include the average man on the street.

As books in these libraries did not circulate, they had to be used in the library rooms themselves. Catalogs, when they existed, were still unsophisticated; consequently, it was the orderly arrangement that guided the reader to the literature. At the end of the seventeenth century, detailed classified arrangements, already popular in the smaller libraries, spread to the larger ones. With the eighteenth century they became more systematic, a reasonable corollary to the Age of the Enlightenment's preference for encyclopedic thought. A logical and systematic order was considered an indispensable aid for the scholar to guide him to what he needed.
There were sizable collections, such as the library of the Elector of Saxony in Dresden, whose 174,000 volumes until 1796 were accessible solely because of their detailed systematic arrangement. ${ }^{9}$ Many theoretical treatises supported such detailed orders. Particularly well known was Konrad Gesner's Pandectae sive Partitiones universales (Zürich, 1548), a subject guide to his Bibliotheca universalis (Zürich, 1545). It followed the existing university faculties and became a model for the arrangement of books on the shelves. ${ }^{10}$

\section{Abandonment of Open Shelves}

Toward the end of the eighteenth century two practices emerged which created barriers in the traditional reader/book relationship and which greatly influenced modern library practice and theory. One was the fact that until the middle of the nineteenth century, modern conveniences, such as heat and lighting, were slow in finding their way into libraries. To make studying more comfortable, small rooms were made available for reading purposes in the larger libraries. These rooms could be easily heated and, furthermore, allowed observation of readers. ${ }^{11}$ Now the user was no longer surrounded by the collection; the needed volumes had to be delivered to the reading room for use there. It was only a small step to close off the book rooms themselves and to admit the users to the reading rooms only.

The other factor contributing to the closing of stack areas was the steady growth in the amount of scholarly literature. The most efficient way to shelve incoming material seemed to be in large multitier stacks with parallel ranges close together to increase the storage capacity. Thus stacks were created as separate areas from the rooms where the books were used. Increasingly, the reading rooms became the only areas open to readers, while the stacks were 
closed or, in rare circumstances, open only to privileged users. Closing of stack areas also helped to prevent losses.

Other developments during the nineteenth century also had an influence in this change. Many new universities had been established in Western Europe during the second half of the century. New disciplines were created in which research was encouraged. Academic communities more than doubled in some countries and depended on the university libraries to support their scholarly pursuits. However, as library appropriations did not increase proportionately, large libraries found themselves tied to administrative practices which were inadequate to cope with the many new books to be processed and with greater demands for services. A bottleneck was the shelflist, which had to serve both for location control and as the library's subject catalog. The addition of new volumes necessitated a constant shifting of the books on the shelves, changes of already cumbersome notations, and adjustments in the catalog. As a consequence of such complicated operations, backlogs of unprocessed books developed.

The only solution to this problem seemed to be the abandonment of the prevailing subject arrangement of the literature on the shelves and the employment of the most economical storage possible. Thus the systematic library catalog could be relieved of its shelflist function, and new accessions could be integrated much more speedily. The results of this decision were far-reaching. The abandonment of any systematic order on the shelves made it unprofitable for a reader to go to the stacks directly, since similar material would no longer be together. The closing of shelves to readers was a logical consequence of a nonsystematic arrangement. Librarians ever since have rationalized this decision.
The new method, born of necessity, employed a shelf-finding device based on sequential numbering. This method was not actually a new one, as evidenced in the catalogs of Durham (twelfth century), or Canterbury (around 1300), where new acquisitions were added in numerical order after an initial subject grouping. ${ }^{12} \mathrm{~A}$ famous example of this arrangement, heavily criticized by Naudé, was the arrangement of the collection of the Ambrosiana in Milan (1602). ${ }^{13}$

The nineteenth century pacesetter for shelving order by accession number was the Bibliothèque Nationale in Paris, and from there it spread rapidly to other western European countries. As the Bibliothèque Nationale had been unable to process the overwhelming flood of incoming works, a decision was made to close the old stacks where books had been grouped by subject and to start a "classement méchanique," which, due to official instructions, was now de rigueur for the large libraries under the central control of the French government.14 When Léopold Delisle, who was then also director of the Bibliothèque Nationale, suggested in his influential handbook on library practices a numerical arrangement of new works, the French municipal libraries voluntarily followed these recommendations..$^{15}$ Strict numerical order was found to be particularly economical when the material was first grouped according to size. As recently as the 1937 edition of Crozet's standard handbook, grouping into nine sizes for scholarly libraries and into six for public libraries was proposed. ${ }^{16}$

The French pattern of strict numerical arrangement within a size group did not find general acceptance in German academic libraries even though they had experienced the same financial problems and were faced with the same backlogs. There the emerging library profession had developed the "subject specialist- 
librarian," who was responsible for the building and organization of the collection in his field of specialization and in related subject areas. A strict numerical order would scatter the works in his field, separate him from the collection, and prevent him from evaluating its strength and weaknesses. Since collection building was the librarian's prime responsibility, such an arrangement was not considered suitable. ${ }^{17}$ Instead, the arrangement adopted by German libraries was a modification of the French practice, in which the material was first divided into subject groups and then subdivided according to book size and accession number. Numerical arrangement in these two forms spread rapidly among the scholarly libraries in Europe. ${ }^{18}$ As a result, with the exception of reference collections in reading rooms, scholarly libraries had closed stacks.

A major debate on the advantages of numerical vs. systematic arrangement and the issues closely connected with it -open shelves vs. closed shelves-then took place. Administrative and economic considerations had the upper hand, and Georg Leyh, the foremost defender of numerical arrangement, pronounced the "dogma of systematic arrangement" as anathema, and created a new dogma of the numerus currens. ${ }^{19}$ According to Leyh, Fritz Milkau, then director of the Prussian State Library, had reasoned that 90 percent of all reader requests were for material of the last decade. Leyh concluded, therefore, that an arrangement according to acquisition by the library would be most practical. As new books would be shelved together, the library attendant could find the requested volumes within a small area and could deliver them quickly to the circulation desk. Leyh argued further that because of the continuing lack of funds, space, and personnel, the arrangement by classification created large backlogs and that new accessions could not easily be accommodated by the frequently complicated notation systems. $\mathrm{He}$ also expounded the obsolescence of existing classification schemes and the great efforts involved in keeping pace with the development in all branches of knowledge required to update the systems. He reasoned that it was impossible to assemble all the literature on a subject in one place, since classification schemes separated works and placed them in many locations in the system according to a variety of disciplines. Consequently, researchers would have to gather material from many locations. They would do much better to find the needed works through the traditional bibliographical sources and thus avoid the wasted time hunting through the stacks. $^{20}$

As Leyh had indicated, a sequential order keeps new material generally together in annual layers, and whole sections can thus be easily removed and placed elsewhere. Following Leyh's thinking, some large libraries have created separate chronological sections, such as the Vittorio Emanuele in Rome which has ten chronological groups, and the Zürich Zentralbibliothek where there are four such sections, two already transferred to a storage facility. ${ }^{21}$

The adoption of a mechanical arrangement and the resulting exclusion of students from the stacks isolated the European university library and fostered, especially in Germany, the development of institute libraries. These latter are characterized by open shelves and quick acquisition of special literature. They receive strong financial support from the university administration because the faculty, recognizing the value of open shelves which bring the students into immediate contact with the literature of their field, present strong cases for them. 


\section{Open Shelves in American Libraries}

While most prominent European university libraries excluded their students from direct access to their collections, the public library movement in the United States prospered and had already begun to influence public library theory in Scandinavian countries. The American brand of democracy determined the development of a philosophy of public library work which was different from that in central European countries. Within this movement "open access" to the collection was the most radical and tradition-breaking innovation. It emerged as a library technique which again had the needs of the reader in mind and thus signified a return to the direct book/reader relationship of old. Many sociopolitical developments contributed to its general acceptance, but the influence of a few factors was particularly strong. Some college libraries which allowed their students free access to their collections may have served as examples for public libraries. As these libraries and the student bodies served were both small, it was natural to use the available books directly in the library rooms. At Brown University this practice had begun in 1848; Cornell was another early example; and at Mt. Holyoke Seminary, teachers and students could study in comfortable alcoves in which the books were arranged. ${ }^{22}$ The democratic concept of equal opportunity for all citizens demanded the acceptance of this policy in public libraries. In addition to teachers and clergymen who already had access to the shelves of public libraries, ${ }^{23}$ extensions of this privilege to others now became reasonable. ${ }^{24}$

Not all librarians, however, subscribed to this belief. The idea of extending library services to an "unknown public" generated arguments, which can be followed for several decades in the editorials and articles of the Library Journal and in the reports and debates of the ALA conferences. Many pessimistic prophecies were made for libraries if book stacks were opened. It was feared that theft, misplacements, and mutilations would be rampant. However, there seemed never to be any doubt that open shelves would contribute significantly to the self-education of interested citizens. Librarians were well aware that open shelves were not a panacea for everyone. The general reader would be at a loss in a large collection and would not know where to turn, whereas the serious student, knowing what he wanted, could find it quickly. ${ }^{25}$ At the conference of librarians held in London in 1877, the majority spoke against open access; even forward-looking Melvil Dewey was one of them. ${ }^{26}$ The subject was again debated at the ALA conferences at San Francisco in 1891 and at Lake Placid in 1894. However, at Atlanta in 1899 and at Montreal in 1900, members were now overwhelmingly in favor of open access. ${ }^{27}$ The tide had turned.

Many foreign visitors to American and British public libraries, where similar practices had emerged, were impressed with open shelves, "le grand avenir des bibliothèques," and described them enthusiastically. ${ }^{28}$ But, except for the Scandinavian countries, the impact upon European continental librarianship was not great. Open access libraries were the exception in France and Germany, not to mention southern European countries. A British writer, Derrick J. Bott, called the German practicewhich he considered general throughout Europe-the most highly developed closed system. ${ }^{29}$ Its purpose was to educate, and this was thought to be best accomplished when the staff had close contact with readers. Closed stack collections were characteristic of all types of libraries in continental Europe. As 
shown earlier, in university libraries this practice was the result of administrative considerations.

\section{THE IMPACT OF WORLD WAR II}

World War II had a great impact upon continental librarianship. It marked a new beginning and brought about drastic changes in library philosophy and services. Many buildings and catalogs were destroyed and valuable collections and treasures dispersed or lost. Much work and thought was necessary to rebuild and reorganize libraries. The library situation in Germany presented a particularly interesting case, because destruction from the war and the influence of the political ideologies of the occupying powers gave a new orientation to the reconstruction efforts.

After the war, German academic libraries were much concerned with making the remaining collections available as quickly as possible. To expedite this process, prewar administrative methods were chosen again because they had already proved to be efficient and economical. Books were arranged in most libraries by size, with a numerical suborder ${ }^{30}$ Philosophical considerations were postponed for later exploration.

However, public libraries in Germany were in a different situation. They had been of little importance and influence, but now a new era had begun. As a part of the democratization process introduced by the occupying powers, a new comprehensive school system was created with equal educational opportunities for all. Information programs were set up and cultural exchanges established to demonstrate in a most practical way accomplishments from abroad. As a result, different attitudes developed, and they created new demands for reading and information. In turn, they also had a strong impact on the development of public libraries. Wellpublicized examples of American li- brarianship in major German cities were the Amerika Häuser with their open stack libraries. The impressive Amerika Gedenkbibliothek in Berlin, established with United States funds, was a highly visible and advertised German library which demonstrated American practices soon imitated by a generation of new public libraries.

The open shelf policy is a natural practice in a public library where the collections are current and small enough to be meaningful to a browser. Even though German academic libraries could no longer remain insensitive to the open shelf policy demonstrated so effectively by the American example and by the new emerging public libraries, the academic libraries had large, specialized collections which were not classified and which were frequently housed in buildings unsuited to change. Their strongly defended tradition gave priority to collection building rather than to service.

German visitors to the United States observed, however, that the openness of the American research library had made it more and more a center of study. The open shelves and study cubicles had brought scholars and books together rather than separating them. ${ }^{31}$ It seemed obvious that the American library was oriented towards its clientele and that its services were determined by the needs of its users. Several papers read at the 1956 conference of academic librarians in Berlin surveyed the situation and explored the function of the academic library in postwar Germany. It had become evident that the general university library had isolated itself because of its closed stack policy and its restricted rules of access, and so institute libraries grew rapidly. These latter, because of their open shelves and ease of use, had developed at such an astounding rate that in 1966, according to Pflug, 80 percent of the acquisitions budgets of two 
North German universities had been allotted to them rather than to the general university library. ${ }^{32}$ It was argued that, if the university library again wanted to assume its role as a center of research, it must give priority to new research requirements and to needs of its clientele.

Open shelves, the historically natural relationship with library users, appeared now as the pivotal point which could again regain for the library its central role within the organization it was supposed to serve. ${ }^{33}$ It was also recognized that, because German traditions and conditions were different from those in the United States, foreign practices could not be adopted without scrutinizing their suitability and adaptability. ${ }^{34}$

The old arguments concerning closed shelves and open shelves were once more the center of debate. It was agreed that administrative considerations could no longer dictate library practice and that new approaches had to be explored. In order to bring the readers back into focus, they had to be identified. The German academic library served two distinct groups: the research worker and the student. The researcher still sought access to a highly specialized literature primarily through traditional catalogs, bibliographies, and indexes; the student, particularly the beginner, was part of a rather homogeneous group that relied heavily on general literature to satisfy class requirements. A solution had to be found that would meet the needs of both of these groups.

\section{The Compromise}

Open access as demonstrated in Anglo-American countries did not seem to be an ideal solution for German research libraries. For some time it had been evident that there is a maximum size for an open shelf collection beyond which open shelves become a liability and a luxury, and even a disservice to readers and staff. ${ }^{35}$ The concept of free access, which was originally conceived as an aid to the user, had in the transition from the small library to the large brought with it many of the difficulties which it had proposed to eliminate.

A compromise has evolved in the practice of German academic libraries. In order to serve both groups of readers, closed stacks are used to house the specialized research material, and divisional reading rooms have been developed for students in their first years of study, as well as for general readers. Closed stack areas are dictated by the architectural plan of the older library buildings, by the sequential arrangement of the collections which would be very costly to classify, and mostly by the belief that browsing is not a profitable activity for the research worker. The reading rooms, which originally housed primarily the noncirculating reference collections are now enlarged to include a scaled-down version of the entire library collection. This practice has become the subject of much discussion: How large should the open collection be? What should it contain? How should it be arranged? How should the reader be instructed in its use?

The character and size of the library itself must determine the number and size of the divisional reading rooms. ${ }^{36}$ The purpose of the open collection is to put students into immediate and direct contact with a well-selected basic body of literature in their fields of study. The collection could be rather large, with 100,000 volumes still considered acceptable. ${ }^{37}$ The literature assembled must always represent an integral unit and must not be a collection of disjointed small subject groups. Users must be able to perceive their subject fields in their entirety, both in their organization and in connection with related areas. ${ }^{38}$ This is true whether there is a large reading room or several smaller reading rooms. In the university library at Constance, for example, there is no 
general library collection but a number of special reading rooms. ${ }^{39}$

Kluth suggested that the open collection should contain a good representation of the literature most frequently used, works of established value on a given subject, and important new relevant titles, but excluding historical works. The currency and relevance of the assembled literature must be scrutinized daily; requests received at the reference desk and titles popular in circulation should guide in this task. ${ }^{40}$ This maintenance of the collection is an important responsibility for librarians, providing another dimension to their work. In order to keep like material together, the reading room collections should not be divided into several groups according to size. Because open shelf collections are designed with the general reader in mind, teaching is an important activity for the librarian involved. As in all defenses of open access, the fact that it also supports academic teaching has not been overlooked. ${ }^{41}$

Just as German librarians in their consideration of the concept of open access have evolved the above compromise, librarians in the United States and England, traditionally the strongest defenders of open shelves, are beginning to reexamine their ideas. In many cases open shelves have become an anachronism no longer serving the needs of the modern research worker. Critics are aware, for example, that the large number of books assembled in a university library on a given subject defeats browsing. ${ }^{42}$ Furthermore, in his recent study George Piternick concluded that "it is no longer realistic to hope to provide the same degree of accessibility to every item in [the university's] ever growing stocks." 43

Several developments indicate the desire to restore to the user a manageable body of literature. This is evidenced in the transfer of little-used material from open access into storage libraries, in the formation of departmental and divisional libraries, and in the growing number of undergraduate libraries on large university campuses. Leyh's argument of sixty years ago, pointing to the impossibility of keeping all of the library's holdings on a subject together, has been emphasized today by the tremendous overlapping in modern disciplines. The prevailing classification systems scatter subject matter widely. Journals are at the heart of research in many disciplines, and their contents are retrievable only through bibliographical sources, not through browsing. A further fragmentation has arisen because of information available in new formats that cannot be easily interfiled in a regular shelf sequence. This is the case not only for audiovisual materials, such as tapes and cassettes, but also for the increasing number of publications in microform.

Another modern development which makes browsing for the researcher impossible is the fact that no longer can the large library present the universitas litterarum. As these libraries are forced into greater specialization, the universality of knowledge must be reconstructed cooperatively through coordinated acquisition plans, reference networks, and costly interlibrary loan activities.

The need to control the growing amount of data in the sciences, which could no longer be accessed through traditional classification devices, has resulted in externally produced data bases in machine-readable form. Access to such data bases is provided through terminals located in libraries. According to a recent survey of the Association of Research Libraries, computer-based bibliographic searching has already become a viable and effective research tool in university libraries..$^{44}$ In this process, material of high interest potential can be retrieved in great specificity and in many combinations and much more 
effectively than through traditional browsing in the stacks.

As a result, the arguments for browsing on open shelves for the sake of serendipity, are no longer convincing. Through browsing, the researcher can access only a small portion of the library's potential information resources with a great expenditure of his time. In terms of modern efficiency, the high costs of classifying an entire research collection and of housing it in a systematic manner are, therefore, seemingly out of proportion to the alleged benefits a relatively small group of users may derive.

\section{ConcLusion}

The solution worked out by German research libraries is interesting and may be adopted by other large research libraries: closed stacks, employing compact shelving, for research literature and modern reading rooms tailored to the requirements of general readers. The traditional retrieval method via catalogs and indexes for the libraryowned specialized literature could be supplemented by computer technology that allows access to an enormous amount of data in machine-readable form at remote locations. The librarian will work closely with the researcher in the formulation of the search procedure and exploration of informational sources available. Consequently, there would be a "far more flexible interaction than would result by wandering through the stacks, as if one were shopping in a supermarket." 45

With specialized collections made available through catalogs, bibliographies, indexes, and terminals, the general collection housed on open shelves could be arranged according to traditional classification schemes or perhaps by more functional methods to meet user needs. As some modern studies have indicated, these differ widely in various areas. ${ }^{46}$

The above considerations indicate that the practice of making the entire holdings of a research library available on open shelves may no longer be justifiable in terms of economic efficiency and reader needs. In times of budgetary stringencies it is always beneficial to look to history, to inquire into practices used elsewhere, and to reexamine current methods. The provision of a combined closed and open shelf arrangement can reconcile a library philosophy of service with the requirements of modern administrative principles.

\section{REFERENCES}

1. Carl Wendel, "Das griechisch-römische Altertum," in Georg Leyh, ed., Handbuch der Bibliothekswissenschaft, 2. Aufl. (Wiesbaden: Harrassowitz, 1955) 3, pt. 1:140.

2. Georg Leyh, "Aufstellung und Signaturen," in Handbuch der Bibliothekswissenschaft (Wiesbaden: Harrassowitz, 1961) 2:688.

3. Wendel, "Das griechisch-römische Altertum," p.140-41; Leyh, "Aufstellung," p.685.

4. Richard Aungerville, The Love of Books: Being the 'Philobiblon' of Richard de Bury (London: Burns \& Oates, 1905), p.116-17.

5. Carl Christ, "Das Mittelalter," in Handbuch der Bibliothekswissenschaft 3, pt. 1: 271.

6. Ibid., p. 430 .

7. Gabriel Naudé, Advice on Establishing a
Library (Berkeley: Univ. of California Pr., $1950)$, p.74.

8. Ludwig Klaiber, "Die französischen Bibliotheken seit der Renaissance," in Handbuch der Bibliothekswissenschaft 3, pt. 1:704-5.

9. Georg Leyh, "Die deutschen Bibliotheken von der Aufklärung bis zur Gegenwart," in Handbuch der Bibliothekswissenschaft 3, pt. 2:121.

10. Ibid., p.129.

11. Gustav Abb, "Die Bibliotheksbenutzung," in Handbuch der Bibliothekswissenschaft $2: 417$.

12. Leyh, "Aufstellung," p.698.

13. Naudé, Advice, p.68.

14. "Circulaire à propos de l'instruction générale relative au service des bibliothèques 
universitaires, 1878," cited by Hugo Alker, "Aufstellung und Signaturen der Universitätsbibliothek Wien, ein Beitrag zur Geschichte des numerus currens," Zentralblatt für Bibliothekswesen 68:242 (1954).

15. Léopold Delisle, Instructions élémentaires et techniques pour la mise et le maintien en ordre des livres d'une bibliothèque, 4 . éd. (Paris, 1910).

16, Leo Crozet, Manuel pratique du bibliothecaire, nouvelle éd. (Paris: Librairie Emile Nourry, 1937), p.78, 81.

17. Leyh, "Die deutschen Bibliotheken," p.378.

18. Alker, "Aufstellung und Signaturen," p.243.

19. Zentralblatt für Bibliothekswesen 29:241 (1912); 30:97 (1913); 31:398 (1914).

20. Zentralblatt für Bibliothekswesen 30:131 (1913).

21. Walter Bauhuis, "Katalogprobleme und Lösungen," Zentralblatt für Bibliothekswesen 61:112 (1947).

22. U.S. Office of Education, Public Libraries in the United States of America, Their History, Condition and Management (Washington, D.C.: U.S. Govt. Print. Off., 1876), p. $90,108$.

23. Herbert Putnam, "Access to the Shelves, a Possible Function of Branch Libraries," Library Journal 16:65 (1891).

24. Frederick J. Teggart, "Access to the Shelves," Library Journal 24:667 (1899); Thomas Wentworth Higginson, "Access to Shelves," in Arthur Bostwick, ed., The Library Without Walls (New York: Wilson, 1927), p.155.

25. Teggart, "Access to the Shelves," p.671.

26. Library Journal 2:272 (1877).

27. "Dana at the Montreal Conference," $\mathrm{L} i$ brary Journal 25:153 (1900).

28. Eugene Morel, Bibliothèques (Paris: Mercure de France, 1908) 2:181.

29. Derrick J. Bott, "Fifty Years of Open Access," Library Association Record 46:212 (1944).

30. Aranka Racz, "Széchényi-Bibliothek und deutsche Staatsbibliothek, Zentralblatt für Bibliothekswesen 71:426-45 (1957).

31. Hermann Tiemann, "Neue Lesesaalaufga- ben in den wissenschaftlichen Bibliotheken," Zeitschrift für Bibliothekswesen und Bibliographie 3:175 (1956).

32. Joachim Stolzenburg, "Bibliothekssystem und systematische Aufstellung," Zeitschrift für Bibliothekswesen und Bibliographie 14: 305 (1967).

33. Rolf Kluth, "Die Freihandbibliothek," Zeitschrift für Bibliothekswesen und Bibliographie 7:109 (1960).

34. Tiemann, "Neue Lesesaalaufgaben," p.172.

35. F. W. Ratcliffe, "Problems of Open Access in Large Academic Libraries," Libri 18:109 (1968).

36. Kluth, "Die Freihandbibliothek, p.106.

37. "Freihandbibliothek," Lexikon des Bibliothekswesen (Leipzig, 1969), p.265.

38. Tiemann, "Neue Lesesaalaufgaben," p.174.

39. Stolzenburg, "Bibliothekssystem," p.308.

40. Kluth, "Die Freihandbibliothek," p.99-100.

41. Peter Moosdorf, "Zur Problematik der Freihandausleihe in Hochschulbibliotheken, Thesen und Vorschläge," Zentralblatt für Bibliothekswesen 86:152-64 (1972).

42. Gilbert W. King, Automation and the Library of Congress, a Survey Sponsored by the Council on Library Resources (Washington, D.C.: Library of Congress, 1963), p.23.

43. George Piternick, "Book Storage in Academic Libraries, a Report Submitted to the Council on Library Resources" (Vancouver, 1974).

44. Jeffrey J. Gardner, David Wax, and R. D. Morrison, Jr., "The Delivery of ComputerBased Bibliographic Search Services by Academic and Research Libraries," ARL Management Supplement 2 (Sept. 1974).

45. King, Automation and the Library of Congress, p.23.

46. F. Celoria, "The Archaeology of Serendip," Library Journal 94:1846-48 (May 1, 1969); S. M. Apted, "General Purpose Browsing," Library Association Record 73: 228-30 (1971); Philip M. Morse, "Search Theory and Browsing," Library Quarterly 40:391-408 (1970). 


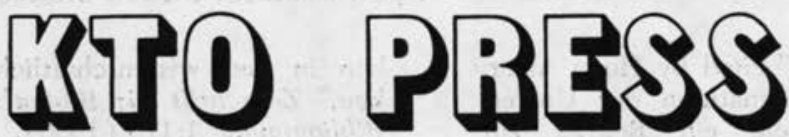

List of new and forthcoming titles

Istoricheskie Zapiski. Index

Vols. 1 - 90 (1937 - 1972).

Compiled by Angelika Schmiegelow Powell.

1 vol. Nendeln, 1976. clothbound SFr. $\quad 54.00$

The index is in two sections. The Author Index is in the Cyrillic alphabet; listed in it are approximately 1000 authors with the titles of the articles to which they refer. The Subject Index contains about 2630 entries which follow the Library of Congress Subject Heading List. Each heading is followed by the transliterated name of the author, the volume and page numbers which identify the article. The Library of Congress transliteration system is used throughout.

\section{Oeuvres de l'Abbé Grégoire.}

With an introductory essay by Albert Soboul, Sorbonne. 143 works originally published in Paris, Versailles etc. between 1793 and 1832. clothbound in 14 volumes SFr. 1260.00

Contents:

Vol. I. Grégoire député à l'Assemblée Constituante

Vol. II. Grégoire député à la Convention Nationale

Vol. III. Grégoire conventionnel en Mission

Vol. IV. Grégoire, évêque Constitutionnel

Vol. V. Grégoire au Conseil des Cinq-Cents, le Consulat, l'Empire

Vols. VI-VIII. Grégoire et l'abolition de l'esclavage

Vols. IX. Grégoire et l'émancipation des juifs

Vols. X-XI. Grégoire et I'Eglise gallicane

Vols. XII-XIII. Grégoire historien

Vol. XIV. Grégoire et la Restauration; la Mort de Grégoire.

Publication will commence in 1976 and be completed by the end of 1977. All orders for the complete collection placed before 31 st July, 1976 will be invoiced with a $10 \%$ discount on the list price.

Of all the great personalities of the French Revolution, one of the most outstanding and remarkable remains that of the Abbé Grégoire. Uncompromising on matters of doctrine and faith, he yet showed a rare understanding of human nature, and was intensely aware of all the problems of the revolutionary era. All his moral convictions were employed towards the same end: to build up a Christian faith which could exist in unison with the ideals of the revolution.
Great Britain. Cabinet Office. Cabinet History Series. Principal War Telegrams and Memoranda, 1940 - 1943.

London and Nendeln, 1976.

7 vols. clothbound SFr. 945.00

In 1940/41 Winston Churchill started to relay highly confidential information on the war telegrams between London and the Commanders in the Field - to Cabinet Members, Heads of major State Departments and Chiefs of Staff.

The events of two months on average made up one volume, covering the Middle and Far East, India, Africa, telegrams London/Washington, the Russian questions, the situation in Dakar, Norway and after Dunkirk. The most important communications were selected and a limited number run off for distribution.

Ofori, Patrick E.

Black African Traditional Religions and Philosophy.

A select bibliographic survey of the sources from the earliest times to 1974 .

Nendeln, $1975 . \quad$ clothbound SFr.

Ofori, Patrick E. Christianity in Tropical Africa.

A select bibliography. in preparation

Ofori, Patrick E.

Islam in Africa South of the Sahara.

A select bibliographic guide. in preparation

\section{Southampton University Studies in Parliamentary Papers.}

'Ford, G. Select List of Reports and other Papers in the Journals of the House of Commons 1688 - 1800 .

Nendeln, $1976 . \quad$ clothbound SFr.

Marshallsay, Diana, and Smith J.H.

Ford List of British Parliamentary Papers 1965 - 1974.

in preparation

KTO PRESS A Division of Kraus-Thomson Organization Ltd. FL-9491 Nendeln, Liechtenstein 